\title{
Peningkatan Motivasi Dan Hasil Belajar Siswa Dengan Menerapkan Metode Mind Mapping Pada Pembelajaran Pembelajaran Seni Rupa Materi Merancang Dan Menyelenggarakan Pameran Di Kelas IX SMP Negeri 1 Duhiadaa
}

\author{
Meyko Saleh Inaku \\ Smp Negeri 1 Duhiadaa \\ Email:meyikosinaku@gmail.com
}

\begin{abstract}
Received: 13 August 2021; Revised: 02 October 2021; Accepted: 14 December 2021
DOI: http://dx.doi.org/10.37905/aksara.8.1.471-482.2022
\end{abstract}

\begin{abstract}
Abstrak
Peningkatan Motivasi Dan Hasil Belajar Siswa Dengan Menerapkan Metode Mind Mapping Pada Pembelajaran Pembelajaran Seni Rupa Materi Merancang Dan Menyelenggarakan Pameran di Kelas IX SMP Negeri 1 Duhiadaa PTK ini bertujuan untuk meningkatkan hasil belajar seni rupa pada materi merancang dan menyelenggarakan pameran di kelas IX SMP Negeri 1 Duhiadaa Tahun Pelajaran 2018/2019 dengan subyek penelitian sebanyak 32 Peserta didik. Teknik pengumpulan data dilakukan dengan cara observasi kepada guru dan kepada siswa, Tes dan Dikumentasi. Hasil penelitian menunjukkan: Dari hasil analisis data yang diperoleh dari kondisi awal, siklus I,dan siklus II setelah diterapkannya metode mind mapping menunjukkan kemampuan belajar siswa mengalami peningkatan. Hasil rata-rata tes pada kondisi awal sebesar 59,22, meningkat pada siklus I menjadi 70,31 dan pada siklus terakhir menjadi 80,00, sedangkan jumlah siswa yang tuntas sebanyak 12 siswa atau 37,50\% dari 32 siswa pada kondisi awal, menjadi 21 siswa atau 65,63\% dan 28 siswa atau 87,50\% pada siklus terakhir. Penerapan metode mind mapping pembelajaran seni rupa materi merancang dan menyelenggarakan pameran dapat meningkatkan motivasi belajar siswa. Hal ini terindikasi dari peningkatan motivasi belajar menunjukkan peningkatan dari 16 siswa atau 50\% pada studi awal menjadi 24 siswa atau $75 \%$ pada siklus pertama dan 30 siswa atau $93,75 \%$ pada siklus terakhir.
\end{abstract}

Kata Kunci: Hasil Belajar Seni Rupa, Pameran Metode Mid Maping

\section{PENDAHULUAN}

Pendidikan seni rupa di sekolah umum, pada dasarnya diarahkan untuk menumbuhkembangkan kepekaan rasa, serta memiliki daya cipta, sehingga terbentuk kesadaran terhadap nilai-nilai seni budaya. Kemampuan ini dapat tumbuh kembang, bila dilakukan serangkaian kegiatan pengamatan, penilaian, analisis dan penghargaan terhadap karya seni, baik di dalam kelas maupun di luar kelas. Kurikulum Pendidikan Nasional (1993-1994:86) pada mata pelajaran pendidikan seni, bertujuan untuk menanamkan dan mengembangkan cita rasa keindahan dan keterampilan berolah seni, serta rasa cinta dan bangga terhadap seni budaya bangsa Indonesia. Selain itu mata pelajaran pendidikan seni bertujuan untuk menyeimbangkan kemampuan rasional dan emosional." Sedangkan tujuan pembelajaran seni adalah memahami arti seni, mengembangkan kepekaan terhadap seni, mengembangkan estetika, mengembangkan kemampuan berapresiasi, berkarya kreatif “ (Pendidikan Nasional, 1993:1994:87) Proses kegiatan belajar mengajar pendidikan seni rupa, yang mempunyai peranan penting adalah strategi, pendekatan dan metode pembelajaran yang digunakan. Pendekatan dan metode ini menjadi penghubung antara pengajar dengan siswa, dan merupakan sarana pengarah secara timbal balik. Menggunakan pendekatan dan metode 
mengajar yang tepat, akan sangat menentukan pencapaian hasil belajar siswa. salah memilih metode, maka kegagalanlah yang akan didapat. Metode merupakan alat untuk mencapai tujuan. Dalam menetapkan metode dan alat bantu hendaknya tidak menggunakan satu metode mengajar, tetapi kombinasi dari beberapa metode mengajar dengan bantuan alat peraga (Sudjana, 1989: 66).

Pada pelaksanaan kegiatan belajar mengajar mata pelajaran seni rupa, belum terlaksana kegiatan pemberian pengalaman estetik, ekspresif, dan kreatif. Di lain pihak peserta didik banyak membuang waktu percuma, suasana kelas dengan tingkat gangguan tinggi, keadaan suasana menjemukan, materi pelajaran sulit disampaikan, dan tidak mudah dipahami. Siswa bersikap sinis, apatis, dan karya yang dihasilkan bernilai rendah.

Hal ini tercermin dari perolehan nilai dalam pembelajaran apresiasi seni rupa siswa yang rendah. Dari 32 siswa, hanya 12 siswa (37,50\%) yang mencapai ketuntasan belajar (71). 20 siswa yang lain atau $(62,50 \%)$ belum mencapai ketuntasan belajar dengan penjelasan nilai rata-rata klasikal sebesar 66,72 dan nilai tertinggi 80 dan terrendah 45.

Dari hasil kegiatan prasiklus sebagaimana dijelaskan di atas, terlihat bahwa pembelajaran yang dilakukan lebih mementingkan hasil daripada proses. Pembelajaran demikian menyebabkan siswa jenuh dan bosan. Lebih lanjut, proses pembelajaran tersebut mematikan fungsi kerja otak kanan yang memacu kreativitas. Padahal kreativitas inilah yang sangat diperlukan dalam pembelajaran seni rupa. Pembelajaran yang membosankan tanpa variasi itulah yang tidak membuat siswa merasa enjoy sehingga tidak bisa menghasilkan ide-ide yang kreatif dan imajinatif.

\section{KAJIAN TEORITIS \\ Hasil Belajar}

Setiap melaksanakan kegiatan tertentu akan diperoleh suatu hasil, begitu pula dengan hasil belajar. Hasil kegiatan belajar biasa dikenal sebagai hasil belajar. Hasil belajar mempunyai ukuran keberhasilan peserta didik melaksanakan belajar. Keberhasilan siswa dalam kegiatan belajar, salah satunya dapat dilihat dari nilai tes yang diperoleh oleh siswa. Hasil belajar ini diperoleh melalui seperangkat tes dan hasil tesnya akan memberikan informasi apa yang telah dikuasai peserta didik. Hasil belajar (achievement) diartikan sebagai tingkat keberhasilan dengan mempelajari mata pelajaran di sekolah yang dinyatakan dalam bentuk skor yang diperoleh dari hasil tes mengenai sejumlah mata pelajaran tertentu (Hadari Nawawi, 1981:100).

Nilai yang diperoleh setiap siswa dalam tes hasil belajar tidak selalu sama. Banyak faktor yang mempengaruhi hasil belajar siswa. Adapun faktor-faktor yang mempengaruhi prestasi belajar siswa yang dikemukakan M. Ngalim Purwanto (2007 : 107) ada dua macam, yaitu : faktor dalam dan faktor luar. Untuk faktor yang berasal dari dalam yaitu berupa faktor fisiologi (kondisi fisik, kondisi panca indra) dan faktor psikologi (bakat, motivasi, kecerdasan dan kemampuan kognitif). Untuk faktor luar terdiri dari: faktor lingkungan (alam, kondisi orang tua, lingkungan keluarga, lingkungan sekolah, dan lingkungan masyarakat) dan faktor instrumental (kurikulum/bahan pelajaran, guru pengajar, sarana dan fasilitas, manajemen).

Menurut Winkel (1991: 92) motivasi belajar adalah keseluruhan daya pengaruh yang ada di diri siswa yang dapat menimbulkan kegiatan belajar, menjamin 
kelangsungan kegiatan belajar dan memberi arah pada kegiatan itu demi mencapai suatu tujuan. Motivasi belajar mengandung peranan penting dalam menumbuhkan gairah atau semangat dalam belajar, sehingga siswa yang bermotivasi kuat memiliki energi yang banyak untuk melakukan kegiatan belajar. Sementara itu, Hamzah B. Uno (2008 : 23) mengemukakan bahwa motivasi belajar adalah dorongan internal dan eksternal pada siswa-siswa yang sedang belajar untuk mengadakan perubahan tingkah laku, pada umumnya dengan beberapa indicator atau unsur yang mendukung. Hal itu mempunyai peranan besar dalam keberhasilan seseorang dalam belajar.

Secara etimologi, istilah metode berasal dari bahasa Yunani "metodos". Kata ini terdiri dari dua suku kata: "metha" yang berarti jalan atau cara. Metode berarti suatu jalan yang dilalui untuk mencapai tujuan, sehingga dapat dipahami bahwa metode berarti suatu cara yang harus dilalui untuk menyajikan bahan pelajaran agar tercapai tujuan pengajaran (Zuhairini dan Abdul Ghofir, 2008: 54.)

Menurut Nana Sudjana (2005:76) metode pembelajaran adalah, "Metode pembelajaran ialah cara yang dipergunakan guru dalam mengadakan hubungan dengan siswa pada saat berlangsungnya pengajaran”. Sedangkan M. Sobri Sutikno (2009:88) menyatakan, "Metode pembelajaran adalah cara-cara menyajikan materi pelajaran yang dilakukan oleh pendidik agar terjadi proses pembelajaran pada diri siswa dalam upaya untuk mencapai tujuan".

Melalui model pembelajaran guru dapat membantu peserta didik mendapatkan informasi, ide, keterampilan, cara berpikir, dan mengekspresikan ide. Model pembelajaran berfungsi pula sebagai pedoman bagi para perancang pembelajaran dan para guru dalam merencanakan aktivitas belajar mengajar

Metode pengajaran adalah cara-cara pelaksanaan dari pada proses pengajaran atau soal bagaimana tekniknya suatu bahan pelajaran diberikan di Sekolah. Metode mengajar adalah cara yang digunakan guru dalam mengajarkan satuan atau unit materi pelajaran dengan memusatkan pada keseluruhan proses atau situasi belajar untuk mencapai tujuan". Jadi, metode pembelajaran dapat diartikan sebagai cara yang digunakan untuk mengimplementasikan rencana yang sudah disusun dalam bentuk kegiatan nyata dan praktis untuk mencapai tujuan pembelajaran. Oleh karena itu guru harus mampu memilih dan menetapkan metode pembelajaran yang paling efektif dan efisien sesuai dengan kondisi atau situasinya.

Metode peta alur pikir (Mind mapp)

Di bawah secara berturut-turut dideskripsikan teori atau beberapa konsep yang berhubungan dengan (a) pengertian metode peta alur pikir (Mind mapp); (b) langkahlangkah pembuatan peta alur pikir (Mind mapp); dan (c) implementasi metode peta alur pikir (Mind mapp) dalam pembelajaran menulis cerita pendek.

\section{Pengertian Metode Peta alur pikir (Mind mapp)}

Peta alur pikir atau disebut dengan Mind mapp merupakan salah satu metode belajar yang dikembangkan oleh Tony Buzan tahun 1970-an yang didasarkan pada cara kerja otak. Disebut metode, karena peta alur pikir ini berupa urutan langkah langkah yang sistematis. Otak mengingat informasi dalam bentuk gambar, simbol, bentukbentuk, suara musik, dan perasaan. Otak menyimpan informasi dengan pola dan asosiasi seperti pohon dengan cabang dan rantingnya. Otak tidak menyimpan informasi 
menurut kata demi kata atau kolom demi kolom dalam kalimat baris yang rapi seperti yang kita keluarkan dalam berbahasa. Untuk mengingat kembali dengan tepat apa yang telah kita pelajari sebaiknya meniru cara kerja otak dalam bentuk peta alur pikir. Dengan demikian, proses menyajikan dan menangkap isi pelajaran dalam peta-peta konsep mendekati operasi alamiah dalam berpikir (Sugiyanto, 2007: 41).

Peta alur pikir (Mind mapp) adalah alternatif pemikiran keseluruhan otak terhadap pemikiran linear. Mind mapp menggapai ke segala arah dan menangkap berbagai pikiran dari segala sudut (Michael Michalko dalam Buzan, 2007: 2). Senada dengan pendapat tersebut, Buzan (2007: 103) mengungkapkan bahwa Mind mapp adalah alat berpikir kreatif yang mencerminkan cara kerja alami otak. Mind mapp memungkinkan otak menggunakan semua gambar dan asosiasinya dalam pola radial dan jaringan sebagaimana otak dirancang seperti yang secara internal selalu digunakan otak, dan anda perlu membiasakan diri kembali. Mind mapp merupakan cara termudah untuk menempatkan informasi ke dalam otak dan mengambil informasi ke luar dari otak. Mind mapp adalah cara mencatat yang kreatif, efektif, dan secara harfiah akan "memetakan" pikiran-pikiran kita (Buzan, 2007: 4).

1) Langkah-langkah Pembuatan Peta alur pikir (Mind mapp)

Sebelum membuat sebuah peta alur pikir diperlukan beberapa bahan, yaitu kertas kosong tak bergaris, pena, pensil warna, pikiran, dan imajinasi. Buzan (2007: 15) mengemukakan tujuh langkah untuk membuat Mind mapp. Tujuh langkah tersebut adalah sebagai berikut:

a) Mulailah dari bagian tengah kertas kosong yang sisi panjangnya diletakkan mendatar. Mengapa? Karena memulai dari tengah memberi kebebasan kepada otak untuk menyebar ke segala arah dan untuk mengungkapkan dirinya dengan lebih bebas dan alami.

b) Gunakan gambar atau foto untuk ide sentral. Mengapa? Karena sebuah gambar bermakna seribu kata dan membantu otak menggunakan imajinasi. Sebuah gambar sentral akan lebih menarik, membuat otak tetap terfokus, membantu otak berkonsentrasi, dan mengaktifkan otak.

c) Gunakan warna. Mengapa? Karena bagi otak, warna sama menariknya dengan gambar. Warna membuat Mind mapp lebih hidup, menambah energi pada pemikiran kreatif dan menyenangkan.

d) Hubungkan cabang-cabang utama ke gambar pusat dan hubungkan cabang cabang tingkat dua dan tiga ke tingkat satu dan dua, dan seterusnya. Mengapa? Karena otak bekerja menurut asosiasi. Otak senang mengaitkan dua (atau tiga atau empat) hal sekaligus. Bila cabang-cabang dihubungkan akan lebih mudah dimengerti dan diingat.

e) Buatlah garis hubung yang melengkung, bukan garis lurus. Mengapa? Karena garis lurus akan membosankan otak. Cabang-cabang yang melengkung dan organis seperti cabang-cabang pohon jauh lebih menarik bagi mata.

f) Gunakan satu kata kunci untuk setiap garis. Mengapa? Karena kata kunci tunggal memberi lebih banyak daya dan fleksibilitas kepada Mind mapp.

g) Gunakan gambar. Mengapa? Karena seperti gambar sentral, setiap gambar bermakna seribu kata.

4.Pembelajaran Seni Rupa

Konsep pembelajaran seperti dipahami termasuk dalam lingkup aktivitas pendidikan (Syafieci 2006: 38). Kata pembelajaran merupakan persamaan kata 
instruction yang memiliki arti pengajaran. Menurut Hamalik (2008: 57) pembelajaran adalah suatu kombinasi yang tersusun meliputi unsur-unsur manusiawi, material, fasilitas, perlengkapan, dan prosedur yang saling mempengaruhi mencapai tujuan pembelajaran. Tujuan pembelajaran membantu siswa agar memperoleh berbagai pengalaman dan dengan pengalaman itu tingkah laku siswa berubah, baik kuantitas maupun kualitas. Tingkah laku yang dimaksud meliputi pengetahuan, keterampilan, dan nilai-nilai atau norma-norma yang berfungsi sebagai pengendali sikap dan perilaku siswa (Bastomi 2003: 11).

Berdasarkan pendapat di atas dapat disimpulkan bahwa sesungguhnya pembelajaran merupakan upaya memberikan bekal pengetahuan, keterampilan dan nilai-nilai yang berkembang di masyarakat untuk dikembangkan dan dilestarikan oleh peserta didik dari pendidik.

Proses pembelajaran ditandai terjadinya proses komunikasi dan interaksi antara guru dan siswa. Dalam hal ini terjadi proses transaksi pesan (informasi, pengetahuan, ide perasaan, keterampilan dan lain-lain) melalui kata-kata (verbal), tulisan, gambar, bagan, atau simbol simbol lain antara guru sebagai komunikator dan siswa sebagai komunikan atau sebaliknya. Upaya-upaya tersebut dirumuskan dan disesuaikan dengan karakteristik tiap-tiap mata pelajaran di sekolah. Sebagaimana mata pelajaran lain, pembelajaran seni rupa di sekolah diberikan dalam upaya memberikan pengetahuan, keterampilan dan nilai-nilai yang berkembang dalam masyarakat dengan bidang kajian yang amat luas

\section{METODE PENELITIAN}

Pelaksanaan kegiatan penelitian dilaksanakan di SMP Negeri 1 Duhiadaa yang beralamat Jl.Sawah Besar Kecamatan Duhiadaa Kabupaten Pohuwato Provinsi Gorontalo. Penelitian dilaksanakan selama 3 (tiga) bulan mulai bulan Januari 2019 sampai dengan bulan Maret 2019. Secara rinci sebagaimana dijelaskan pada bagian lampiran 2 penelitian tindakan kelas ini tentang Jadwal Kegiatan Penelitian. Subjek penelitian ini terfokus pada peserta didik di kelas IX.3 SMPN 1 Duhiadaa Tahun Pelajaran 2018/2019 yang berjumlah 32 terdiri dari 12 . peserta didik laki-laki dan 20 peserta didik perempuan Teknik pengumpulan data yang digunakan dalam penelitian tindakan kelas ini adalah Teknik Tes, Metode Observasi dan Metode Dokumentasi

Penelitian ini ditempuh melalui dua siklus dengan dua pertemuan pada setiap siklusnya. Dalam melaksanakan penelitian ini tiap siklus terdiri atas empat tahapan, yaitu: perencanaan, pelaksanaan, observasi, dan refleksi. Pelaksanaan setiap siklus didasarkan atas masukan dari siklus sebelumnya

\section{HASIL PENELITIAN DAN PEMBAHASAN}

Pelaksanaan kegiatan penelitian tindakan sekolah pada pembelajaran seni rupa di kelas IX. SMPN 1 Duhiadaa dimulai dengan melakukan persiapan sebagai suatu keharusan untuk mencapai hasil yang benar-benar maksimal. Langkah yang pertama ini disebut pra siklus yang hasilnya nanti akan dibandingkan dengan siklus I dan siklus berikutnya.

Pada tahap pra siklus ini selain peneliti mendampingi guru mitra (observer) dalam kelas penelitian juga melakukan observasi ketika pembelajaran berlangsung. Penjelasan mengenai keadaan pada kondisi awal sebagaimana dijelaskan tabel-tabel di bawah ini. 
Tabel 1 Rekapitulasi Nilai Hasil Tes Formatif Pada Kondisi Awal

\begin{tabular}{|c|c|c|c|c|c|c|c|}
\hline \multirow{2}{*}{ Nilai } & \multirow{2}{*}{$\begin{array}{l}\text { Jumlah } \\
\text { Siswa } \\
\end{array}$} & \multirow{2}{*}{ Capaian } & \multicolumn{4}{|c|}{ Tuntas } & \multirow[t]{2}{*}{ Ket } \\
\hline & & & Ya & $\%$ & Tidak & $\%$ & \\
\hline$\leq 35$ & 0 & 0 & & & & & $\mathrm{BT}$ \\
\hline $36-50$ & 15 & 685 & & & $\sqrt{ }$ & 46,88 & BT \\
\hline $51-60$ & 4 & 235 & & & $\sqrt{ }$ & 12,50 & BT \\
\hline 61-70 & 1 & 65 & & & $\sqrt{ }$ & 3,13 & BT \\
\hline 71-80 & 12 & 910 & $\sqrt{ }$ & 37,50 & & & $\mathrm{~T}$ \\
\hline 81-90 & 0 & 0 & & & & & $\mathrm{~T}$ \\
\hline 91-100 & 0 & 0 & & & & & $\mathrm{~T}$ \\
\hline Jumlah & 32 & 1895 & - & $\mathbf{3 7 , 5 0}$ & - & 62,50 & - \\
\hline Ketuntasan & $\mathbf{3 7 , 5 0}$ & & & & & & \\
\hline Rata-Rata & 59,22 & & & & & & \\
\hline Tertinggi & 80,00 & & & & & & \\
\hline Terrendah & 40,00 & & & & & & \\
\hline
\end{tabular}

Dari hasil tes formatif pada tes pendahuluan sebagaimana tabel di atas dapat dijelaskan bahwa pada kondisi awal hanya terdapat 12 orang siswa atau 37,50\% yang mendapat nilai di atas KKM, dan sisanya sebanyak 20 siswa atau 62,50\% belum memenuhi $\mathrm{KKM}=71$ dengan perolehan nilai rata-rata secara klasikal sebesar 59,22.

Siklus I

Seperti yang telah direncanakan, tindakan siklus I dilaksanakan dalam dua kali pertemuan yaitu hari Senin 19 Januari 2019 dan Kamis 23 Ja nuari 2019 di ruang kelas IX. SMPN 1 Duhiadaa Masing-masing pertemuan berlangsung $2 \times 40$ menit.

Adapun penjelasan mengenai data hasil tindakan sebagaimana dijelaskan di bawah ini. 
Tabel 2 Daftar Nilai Hasil Tes Formatif dengan Metode Mind Mapping Pada Siklus Pertama

\begin{tabular}{|c|c|c|c|c|c|c|c|}
\hline \multirow[b]{2}{*}{ Nilai } & \multirow{2}{*}{$\begin{array}{l}\text { Jumla } \\
\text { h } \\
\text { Siswa }\end{array}$} & \multirow{2}{*}{$\begin{array}{l}\text { Capaia } \\
\mathbf{n}\end{array}$} & \multicolumn{4}{|c|}{ Tuntas } & \multirow[t]{2}{*}{ Ket } \\
\hline & & & Ya & $\%$ & $\begin{array}{l}\text { Tida } \\
\mathbf{k}\end{array}$ & $\%$ & \\
\hline$\leq 35$ & 0 & 0 & & & & & BT \\
\hline$\overline{36-50}$ & 5 & 250 & & & $\sqrt{ }$ & 15,63 & BT \\
\hline $51-60$ & 5 & 285 & & & $\sqrt{ }$ & 15,63 & $\mathrm{BT}$ \\
\hline 61-70 & 1 & 65 & & & $\sqrt{ }$ & 3,13 & $\mathrm{BT}$ \\
\hline 71-80 & 18 & 1395 & $\sqrt{ }$ & $\begin{array}{l}56,2 \\
5\end{array}$ & & & $\mathrm{~T}$ \\
\hline 81-90 & 3 & 255 & $\sqrt{ }$ & 9,38 & & & $\mathrm{~T}$ \\
\hline 91-100 & 0 & 0 & & & & & $\mathrm{~T}$ \\
\hline Jumlah & 32 & 2250 & - & $\begin{array}{l}65,6 \\
3\end{array}$ & - & 34,37 & - \\
\hline $\begin{array}{l}\text { Ketuntasa } \\
\text { n }\end{array}$ & 65,63 & & & & & & \\
\hline Rata-Rata & 70,31 & & & & & & \\
\hline Tertinggi & 85,00 & & & & & & \\
\hline $\begin{array}{l}\text { Terrenda } \\
\text { h }\end{array}$ & 50,00 & & & & & & \\
\hline
\end{tabular}

Dari hasil tes formatif pada tes akhir siklus pertama sebagaimana tabel di atas dapat dijelaskan bahwa pada siklus pertama terdapat 21 siswa atau $65,63 \%$ siswa yang dinyatakan tuntas, dan sisanya sebanyak 11 siswa atau $34,37 \%$ belum memenuhi KKM dengan perolehan nilai rata-rata secara klasikal sebesar 70,31 sehingga belum memenuhi KKM sebesar 71,00.

\section{Siklus II}

Berdasarkan hasil refleksi pada siklus I, disepakati bahwa Siklus II perlu dilakukan. Persiapan dan perencanaan tindakan dilakukan pada hari Senin, 3 Pebruari 2019 di ruang guru SMP Negeri 1 Duhiadaa Dalam kesempatan ini, peneliti menyampaikan kembali hasil observasi dan refleksi terhadap pembelajaran seni rupa yang dilakukan pada siklus I.

Adapun penjelasan mengenai data hasil tindakan sebagaimana dijelaskan di bawah ini. 
Tabel 3 Daftar Nilai Hasil Tes Formatif dengan Metode Mind Mapping Pada Siklus Kedua

\begin{tabular}{|c|c|c|c|c|c|c|c|}
\hline \multirow[b]{2}{*}{ Nilai } & \multirow{2}{*}{$\begin{array}{l}\text { Jumla } \\
\text { h } \\
\text { Siswa }\end{array}$} & \multirow{2}{*}{$\begin{array}{l}\text { Capaia } \\
\text { n }\end{array}$} & \multicolumn{4}{|c|}{ Tuntas } & \multirow[t]{2}{*}{ Ket } \\
\hline & & & $\mathbf{Y a}$ & $\%$ & $\begin{array}{l}\text { Tida } \\
\mathbf{k}\end{array}$ & $\%$ & \\
\hline$\leq 35$ & 0 & 0 & & & & & $\mathrm{BT}$ \\
\hline $36-50$ & 0 & 0 & & & $\sqrt{ }$ & 0,00 & BT \\
\hline $51-60$ & 1 & 60 & & & $\sqrt{ }$ & 3,13 & BT \\
\hline $61-70$ & 3 & 200 & & & $\sqrt{ }$ & 9,38 & BT \\
\hline 71-80 & 13 & 1005 & $\sqrt{ }$ & $\begin{array}{l}40,6 \\
3\end{array}$ & & & $\mathrm{~T}$ \\
\hline 81-90 & 14 & 1200 & $\sqrt{ }$ & $\begin{array}{l}43,7 \\
5\end{array}$ & & & $\mathrm{~T}$ \\
\hline 91-100 & 1 & 95 & $\sqrt{ }$ & 3,13 & & & $\mathrm{~T}$ \\
\hline Jumlah & 32 & 2560 & - & $\begin{array}{l}87,5 \\
0\end{array}$ & - & 12,50 & - \\
\hline $\begin{array}{l}\text { Ketuntasa } \\
\text { n }\end{array}$ & 87,50 & & & & & & \\
\hline $\begin{array}{l}\text { Rata-Rata } \\
\text { Tertinggi }\end{array}$ & $\begin{array}{l}80,00 \\
95,00\end{array}$ & & & & & & \\
\hline $\begin{array}{l}\text { Terrenda } \\
\text { h }\end{array}$ & 60,00 & & & & & & \\
\hline
\end{tabular}

Dari hasil tes formatif pada tes pada akhir siklus kedua sebagaimana tabel di atas dapat dijelaskan bahwa pada siklus kedua terdapat 28 orang siswa atau $87,50 \%$ yang mendapat nilai di atas KKM, dan sisanya sebanyak 4 siswa atau $12,50 \%$ belum memenuhi KKM dengan perolehan nilai rata-rata secara klasikal sebesar 80,00, sehingga sudah memenuhi KKM sebesar 71, dan secara klasikal telah memenuhi kriteria ketuntasan yaitu minimal $85 \%$ siswa dinyatakan tuntas.

\section{Hasil Penelitian}

Untuk mengetahui lebih jelas peningkatan kemampuan belajar siswa dari siklus yang satu ke siklus yang lain dapat dilihat pada penjelasan berikut ini

1. Data Peningkatan Kemampuan Belajar Siswa

Setelah melakukan analisa terhadap data yang peroleh dari kondisi awal dan dua siklus yang dilaksanakan maka dapat dapat disimpulkan bahwa penggunaan metode Mind Mapping pada pembelajaran seni rupa materi merancang dan menyelenggarakan pameran menunjukkan peningkatan yang signifikan terhadap peningkatan kemampuan belajar siswa. Penjelasan secara rinci mengenai peningkatan kemampuan belajar siswa dari kondisi awal, siklus pertama dan siklus kedua dapat dilihat pada tabel di bawah ini: 
Tabel 4 Rekapitulasi Peningkatan Hasil Belajar Siswa Pada Kondisi Awal, Siklus I dan Siklus II

\begin{tabular}{|l|l|l|l|l|l|l|}
\hline \hline \multirow{2}{*}{ No } & \multirow{2}{*}{ Siklus } & \multicolumn{4}{|l|}{ Ketuntasan } & \multirow{2}{*}{ Ket } \\
\cline { 3 - 6 } & & T & \% & B & \% & \\
\hline 1 & Awal & 12 & 37,50 & 20 & 62,50 & \\
\hline 2 & Siklus I & 21 & 65,63 & 11 & 34,37 & \\
\hline 3 & Siklus II & 28 & 87,50 & 4 & 12,50 & \\
\hline \hline
\end{tabular}

Untuk lebih jelasnya peningkatan ketuntasan belajar siswa dapat dilihat pada gambar diagram batang berikut ini:

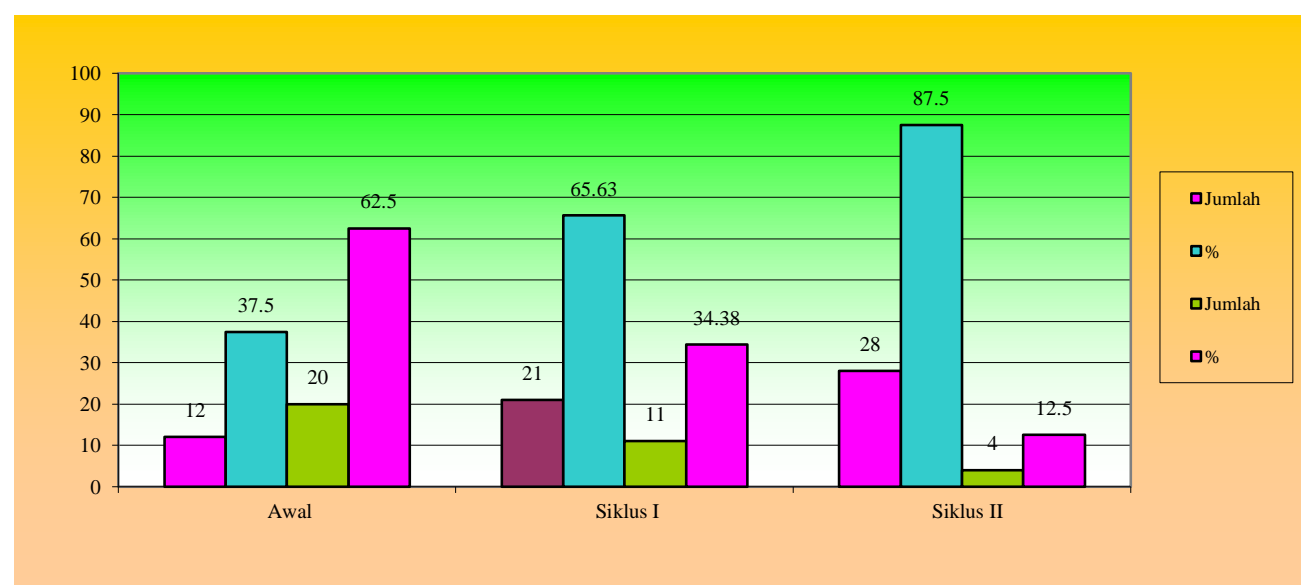

Diagram Batang Peningkatan Hasil dan Ketuntasan Belajar Siswa Pada Kondisi Awal, Siklus I dan Siklus II

\section{KESIMPULAN}

Berdasarkan hasil penelitian dan pembahasan dalam pelaksanaan pembelajaran seni rupa melalui metode mind mapping pada siswa kelas IX.3 SMP Negeri 1 Duhiadaa Semester 2 Tahun Pelajaran 2018/2019 dapat disimpulkan:

1. Pembelajaran dengan menggunakan metode mind mapping dapat meningkatkan proses pembelajaran. Hal tersebut dapat dibuktikan dari perubahan perilaku siswa kelas IX.7 selama mengikuti proses pembelajaran seni rupa melalui metode mind mapping menunjukkan perubahan sikap ke arah yang lebih positif. Sikap positif tersebut diantaranya adalah peserta didik menunjukkan sikap disiplin, aktif, mandiri, berani bertanya dan menjawab, dan merasa nyaman dengan lingkungan belajarnya sehingga tercipta suasana pembelajaran yang kondusif dan menyenangkan.

2. Pembelajaran dengan menggunakan metode mind mapping dapat meningkatkan kemampuan belajar siswa. Hasil rata-rata tes pada kondisi awal sebesar 59,22, meningkat pada siklus I menjadi 70,31 dan pada siklus terakhir menjadi 80,00, sedangkan jumlah siswa yang tuntas sebanyak 12 siswa atau 37,50\% dari 32 siswa pada kondisi awal, menjadi 21 siswa atau $65,63 \%$ dan 28 siswa atau 87,50\% pada siklus terakhir. Penjelasan mengenai peningkatan motivasi belajar menunjukkan 
angka dari 16 siswa atau $50 \%$ pada studi awal menjadi 24 siswa atau $75 \%$ pada siklus pertama dan 30 siswa atau 93,75\% pada siklus terakhir.

\section{SARAN}

Dengan selesainya pelaksanaan penelitian tindakan kelas ini dan pembahasan yang dilakukan pada pembelajaran seni rupa melalui metode mind mapping pada siswa kelas IX.3 SMP Negeri 1 Duhiadaa maka peneliti dengan segala kerendahan hati memberikan beberapa saran, diantaranya, agar dalam mempelajari seni rupa selalu rajin, tekun dan sabar. Pengalaman pembelajaran dengan metode mind mapping sangat mempengaruhi peningkatan kemampuan belajar siswa. Oleh karena itu, tingkatkan praktek dan cara-cara keterampilan kooperatif dalam pembelajaran selanjutnya, guru mata pelajaran kiranya dapat memanfaatkan metode mind mapping sebagai salah satu alternatif teknik pembelajaran dalam penyusunan rencana pelaksanaan pembelajaran untuk meningkatkan efektivitas pembelajaran khususnya tentang materi merancang dan menyelenggarakan pameran karena terbukti dapat meningkatkan kemampuan belajar dan daya serap siswa terhadap materi pembelajaran.

\section{DAFTAR PUSTAKA}

A.M Sardiman. 2009. Interaksi dan Motivasi Belajar Mengajar. Jakarta. PT. Rajawali Pers

Arikunto, Suharsimi. 2002.Penelitian Tindakan Kelas, Jakarta: Bumi Aksara

Arsyad, Azhar, Media Pembelajaran. 2009. Jakarta : PT Grafindo Persada,.

Bastomi, Suwaji.2003. Landasan Berfikir Seni Rupa. Semarang: IKIP Semarang Press.

Beaulieu, Danie, 2008, Teknik-teknik yang Berpengaruh di Ruang Kelas, Jakarta: PT Indeks

Budi Utomo, Kamsijo. 2006. Silabus, Handout, dan Media Pembelajaran Strategi Pembelajaran Seni Rupa

Budiningsih, Asri. 2005. Belajar dan Pembelajaran. Jakarta: Rineka Cipta.

Buzan, Tony. 2007. Mind Map untuk Meningkatkan Kreativitas. Jakarta: Gramedia Pustaka Utama.

De Porter, Bobby. 2003. Quantum Teaching. Bandung: Kaifa.

Departemen Pendidikan dan Kebudayaan. 1993. Kurikulum Pendidikan Nasional : Tujuan Pembelajaran Seni Rupa. Jakarta: Depdikbud.

EM Zul Fajri dan Ratu Aprilia Senja, 2008. Kamus Lengkap Bahasa Indonesia, Edisi Revisi, Cet. 3, Semarang: Difa Publishers

Hadari, Nawawi. 2005. Metode Penelitian Bidang Sosial. Yogyakarta: Gadjah Mada. University Press

Hamalik, Oemar. 2008. Proses Belajar Mengajar. Bandung: Bumi Aksara

Hasbullah Thabrany, 1994. Rahasia Sukses Belajar, Jakarta: PT. Raja Grafindo

Kartini Kartono. (1995). Psikologi Umum. Bandung: Mandar Maju.

Kartini Kartono. 1985. Peranan Keluarga Memandu Anak. Jakarta: CV. Rajawali.

Margono, 2000. Metodologi Penelitian Pendidikan, Jakarta: Rineka Cipta

Nana Sudjana. 1989. Penilaian Hasil Proses Belajar Mengajar. Bandung : PT. Remaja Rosdakarya.

Nana Syaodih, R. Ibrahim dan, 1992. Perencanaan Pengajaran, Jakarta; Rineja Cipta 
Nurhasanah. 2007. Pembelajaran Berbasis Masalah Untuk Meningkatkan Penguasaan Konsep, Berpikir Kritis dan Sikap Ilmiah.Tesis UPI Bandung: tidak diterbitkan.

Olivia, Femi 2008. Gembira Belajar dengan Mind Mapping. Jakarta: Elex Media Komputindo.

Peraturan Pemerintah Nomor 19 Tahun. 2005, tentang Standar Nasional Pendidikan, Jakarta: Depdiknas.

Poerwadarminta ,W. 2007. Kamus Umum Bahasa Indonesia.Jakarta: Balai Pustaka.

Purwanto, Ngalim., 1986, Psikologi Pendidikan, Bandung: Remaja Rosdakarya

Riyanto, Yatim. 1996. Paradigma Baru Pembelajaran. Jakarta: Kencana.

Slameto. 1995. Belajar dan Faktor-Faktor yang Mempengaruhinya. Jakarta: Rineka Cipta.

Sobandi, Bandi. 2008. Model Pembelajaran Kritik dan Apresiasi Seni Rupa. Bandung: Universitas Pendidikan Indonesia.

Sudjana, Nana. 2005. Media Pengajaran. Bandung: Sinar Baru Algensindo.

Sudrajat, Akhmad. 2001. Pengertian Pendekatan, Strategi, Metode, Teknik dan. Model Pembelajaran. Bandung : Sinar Baru Algensindo

Sugiyanto.2007. Model-Model Pembelajaran Inovatif. Modul PLPG.Surakarta: Panitia Serifikasi Rayon 13 Surakarta.

Suroso. 2004. Smart Brain Metode Menghafal Cepat dan Meningkatkan Ketajaman Memori. Penerbit SIC.

Sutikno, M. Sobri, 2009. Belajar dan Pembelajaran: Upaya Kreatif dalam Mewujudkan Pembelajaran yang Berhasil, Bandung: Prospect

Syafii. 2006. Konsep dan Model Pembelajaran Seni Rupa. Semarang: Universitas Negeri Semarang.

The Liang Gie dan Sutarto. 1975. Pengertian Kedudukan dan Perincian Ilmu Administrasi, Yogyakarta: Karya kencana

Thonthowi Ahmad, 1991. Psikologi Pendidikan, Bandung : Angkasa

Tuminto, Didik. 2007. Keterampilan Berbahasa. Jakarta: Rajawali Pres

Uno, Hamzah B. dkk. 2006. Desain Pembelajaran. Bandung: MQS Publishing.

Uno, Hamzah. B. 2010. Perencanaan Pembelajaran. Jakarta:Bumi Aksara.

Wycoff, Joyce. 2003. Menjadi Super Kreatif melalui Metode Pemetaan Pikiran. Bandung: Kaifa.

Zuhairini, H. Abdul Ghofir Slamet As. Yusuf, 2008. Metodik Khusus Pendidikan. Surabaya: Penerbit Usaha Nasional, 
AKSARA: Jurnal Ilmu Pendidikan Nonformal

P-ISSN 2407-8018 E-ISSN 2721-7310 DOI prefix 10.37905

Volume 08, (1), January 2022

http://ejurnal.pps.ung.ac.id/index.php/Aksara 